Journal of Thermal Engineering, Vol. 7, No. 3, pp. 550-569, March, 2021

Yildiz Technical University Press, Istanbul, Turkey

\title{
OPTICAL NUMERICAL INVESTIGATION OF A SOLAR POWER PLANT OF PARABOLIC TROUGH COLLECTORS
}

\author{
Mokhtar Ghodbane ${ }^{1 *}$, Boussad Boumeddane ${ }^{1}$, Ahmed Kadhim Hussein ${ }^{2}$, Dong Li ${ }^{3}$, S. Sivasankaran ${ }^{4}$
}

\begin{abstract}
Going forward towards developing and improving renewable energies in Algeria is one of the main objectives of this study, especially, solar energy that is an exceptional and continuous source of energy. Algerian Sahara has a large area suitable for agriculture, but not connected to the electricity network. Therefore, the construction of solar power plants based on the solar energy concentration has been proposed for the electricity production, which is exploited in the rest of the economic sector of the Algerian state. Through the study conducted under real weather data for the day March $16^{\text {th }}, 2018$, an optical characterization of a solar power plant of parabolic trough concentrator has been convoyed in El-Oued region, Algeria. The geometrical and the optical characteristics of studied solar collector have been determined, such as the optical efficiency, the local concentration ratio, the cosine effect of the incidence angle, the optical losses at the ends of the receiver tube, the shading effect, the blocking effect, and the coefficient of incidence angle modifier and intercept factor. MATLAB code has been used as a program for numerical programming. Of the most important results obtained, it was found that the optical efficiency has exceeded $77.22 \%$. As for the local concentration ratio, its maximum value is equal to 116.30 in the lower part of the receiver tube at the peripheral receiver angles " $\beta=91^{\circ}$ and $269^{\circ}$ ", while the minimum values of this important coefficient were recorded at the top of the receiver tube.
\end{abstract}

Keywords: Solar energy, Power plants, Parabolic trough collector, Optical investigation, Numerical Simulation

\section{INTRODUCTION}

Renewable energies are a major development globally, especially solar energy [1,2], which is the source of the remaining types of renewable energies. Renewable energy sources are preferred, not only because they can meet the global energy shortage that is mostly dependent on fossil energies, but also because renewable energies exist in abundance with sustainable and environmentally friendly energy.

Solar energy is one of the most abundant renewable energy sources in the world. It is a solar radiation that can be used in several fields, the most important of which are: electricity production and charge the batteries [3-7], air conditioning [8-11], heat swimming pools [12], air heating [13-15], water heating [16-18], nanofluids applications [19, $20]$, solar irrigation [21, 22], cook food [23, 24], desalination [25, 26], drying [27, 28] and process heat applications $[29,30]$. For good use and more efficient use of solar energy, there are many techniques for solar collectors that can be used, including the compound parabolic collectors (CPCs) [31, 32], the evacuated tube collectors (ETCs), the Flat-plate collectors (FPCs) [33-35], the Heliostat field collectors (HFCs) [36], the linear Fresnel reflectors (LFRs) [37-39], the parabolic dish reflector (PDRs) [40, 41] and the parabolic trough collectors (PTCs) [42-44]. Based on several rigorous scientific researches, it has been possible to improve the efficiency of the above-mentioned solar collectors using nanoparticles suspended in the working fluid, as the nanoparticles improve the heat transfer inside the working fluid [45-47]. One of the most important scientific researches that dealt with improving the thermal transfer coefficient of working fluids through nanotechnology, studies carried out by Mebarek-Oudina [48], Said et al. [49-52], Raza et al. [53], Bellos and Tzivanidis [54, 55] and Alkasassbeh et al. [56]. However, in order to make the solar collector system effective during the day, the night and in cloudy weather conditions, it is necessary to rely on efficient storage systems for thermal energy to be used when necessary in the absence of a solar energy source.

This paper was recommended for publication in revised form by Regional Editor Mustafa Kılıç

'Department of Mechanical Engineering, Saad Dahlab University of Blida 1, Blida 09000, Algeria

${ }^{2}$ College of Engineering - Mechanical Engineering Department - University of Babylon - Babylon City - Hilla - Iraq

${ }^{3}$ School of Architecture and Civil Engineering, Northeast Petroleum University, Fazhan Lu Street, Daqing, 163318, China

${ }^{4}$ Department of Mathematics, King Abdulaziz University, Jeddah 21589, Saudi Arabia

*E-mail address: ghodbanemokhtar39@yahoo.com

Orcid ID: 0000-0003-1350-8631", 0000-0002-1947-6397, 0000-0002-4360-0159, 0000-0002-2692-9091, 0000-0001-9443-7091

Manuscript Received 28 August 2019, Accepted 27 September 2019 
The subject of this paper is about Parabolic Trough Collectors (PTCs) technology. This solar system was considered the most used especially in power plants, due to its high optical and thermal efficiency [57-59], but somewhat is a high cost compared to linear Fresnel reflector technology. The PTC collector consist of a linear parabolic mirror, which concentrates the beam radiation on a receiver tube positioned along the focal line, in which circulates a working fluid [60-62].

Because of the importance of this type of solar concentrators, there is in the literature a lot of scientific research that has addressed this solar technology with great accuracy, including the work done by Manikandan et al. on identifying ways to enhance and improve the optical and thermal efficiency of PTCs [63]. Moreover, Azzouzi et al. have conducted an experimental study on a PTC with a large rim angle in order to determine the optical comportment of the manufactured prototype [64]. In addition, Moloodpoor et al. have conducted a study on the thermal comportment of PTC solar collectors based on the intelligence swarm enhancer [65]. Beside, Bello et al. conducted a number of scientific research on this effective technique [66-70], where they touched on many areas of technology during their research (Industrial uses, thermal behavior study, optical behavior study, nanoparticle efficiency improvement, etc.). Besides, Korres et al. chose to use nanofluids as a working fluid with a laminar regime with a compound parabolic trough solar collector (CPTC) [32].

On a clear day, the PTC collector follows the sun along one north-south axis of rotation, meaning that the reflective mirror reflects the beam radiation from sunrise east until evening arrives west at sunset. Direct sunlight is not completely perpendicular to the reflective mirror surface, either because of random or non-random errors [57]. For this reason, it was necessary to calculate the geometric and optical coefficients with great accuracy in order to accurately determine the optical efficiency of the studied collector. Consequently, the main objective of this paper is to conduct an optical investigation of a solar power plant consisting of PTC solar collectors, in order to estimate its optical characteristics based on:

- The geometric parameters;

- The optical parameters;

- The change in the climatic conditions of the region of El-Oued, Algeria for the day of March $16^{\text {th }}$, 2018.

Therefore, results obtained will allow engineers' specialists in the construction of PTC solar power plants, knowing all the engineering, design and optical parameters that help determine:

- The change in incidence and sun height angles;

- The distance evolution between two consecutive rows;

- Total optical loss due to random and non-random errors, engineering errors and visual errors;

- The field collector optical efficiency;

- The change in the local concentration ratio "LCR", i.e. the thermal distribution on the absorber tube surface for a PTC collector's model.

Thus, this study is very important in all respects, theoretically for advanced students, and technically for engineers responsible for the construction of power plants, because the fact the visual aspect of such solar collectors is very complex.

\section{MATHEMATICAL EQUATIONS GOVERNING THE OPTICAL MODEL}

The optical investigation of solar collectors is one of the most important physical factors in determining the performance of these collectors. For solar concentrators, the optical properties of the reflective mirrors are characterized by the reflection coefficient of the reflective mirrors " $\rho_{\mathrm{m}}$ ", the transmission coefficient of the glass tube " $\tau$ ", the intercept factor " $\gamma$ " and the absorption coefficient of the receiver tube " $\alpha_{\mathrm{Ab}}$ ".

When solar radiation reaches the collector, a significant amount of energy is lost for three reasons (geometric, optical and thermal). In this work, the design errors and optical errors that are generally associated with parabolic trough solar collector have been discussed. Figures 1(a-b) show the engineering description of the studied solar reflector. 


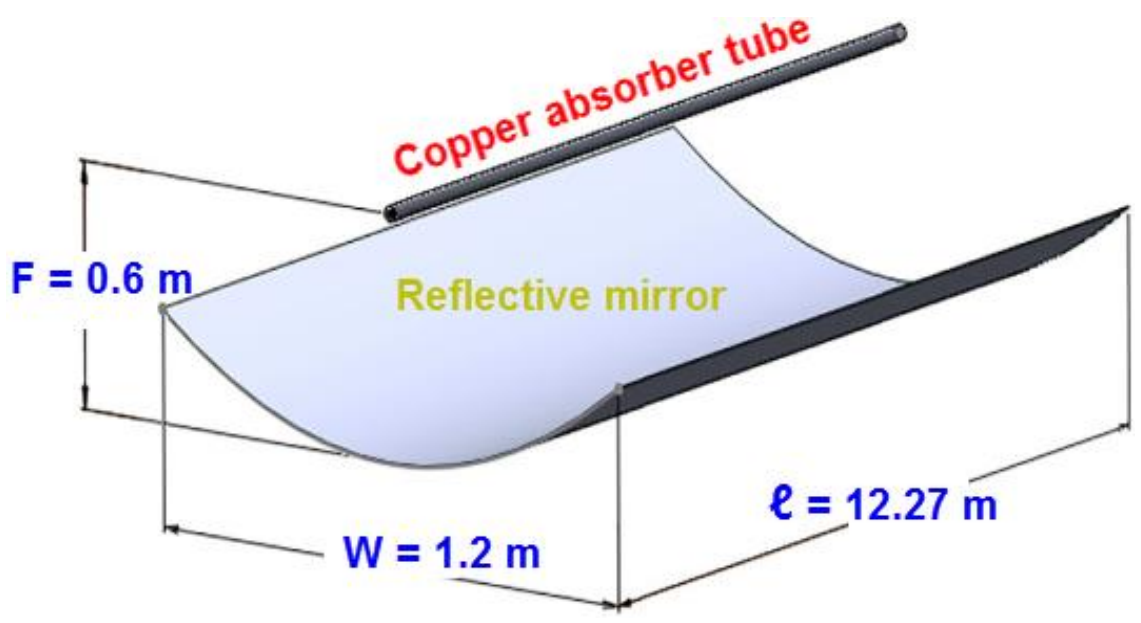

(a)



(b)

Figure 1. Engineering of the studied solar collector: a) Comprehensive appearance [68], b) Cross-section

Table (1) illustrates the geometric characteristics of studied solar reflector. The receiver tube is the main element of the considered reflector, whose role is to absorb incident direct-normal solar irradiance " $\mathrm{DNI},\left(\mathrm{W} / \mathrm{m}^{2}\right)$ ", to transform it into thermal power and to transmit this energy to a fluid heat carrier. Table (2) represents the optical characteristics of elements solar collectors.

In addition, the reflector of the parabolic form is one of the most important parts of studied PTC; its purpose is to concentrate direct-normal solar irradiance in the focal line. Moreover, the reflectors are mirrors that can have different shapes and can be made from different materials depending on the configuration chosen by the exploiter. Based on what has been said previously, the optical losses have a direct relationship with the receiver tube, the reflective mirror and the distance between two successive parabolic trough collectors in the same solar power plant.

\section{Design Errors}

As shown in Figures (2 and 3), design errors are represented in the geometric losses. The optical performance of the parabolic trough collector varies according to the location and time of use, because climatic conditions have a 
direct impact on the efficiency of these collectors [71, 72]. Therefore, the choice of site for the construction of solar power plants is an important factor for good performance of these power plants.

Table 1. Geometric characteristics of studied PTC

\begin{tabular}{|l|c|l|c|}
\hline \multicolumn{1}{|c|}{ Geometric feature } & Value & \multicolumn{1}{|c|}{ Geometric feature } & Value \\
\hline Outer diameter of the absorber $\left(\mathrm{D}_{\mathrm{A}, \mathrm{ext}}\right)$ & $0.016 \mathrm{~m}$ & Curve length of the reflective mirror $(\mathrm{CL})$ & $1.2481 \mathrm{~m}$ \\
\hline Inner diameter of the absorber $\left(\mathrm{D}_{\mathrm{A}, \mathrm{int}}\right)$ & $0.0142 \mathrm{~m}$ & Rim angle $\left(\varphi_{\mathrm{r}}\right)$ & $53.1301^{\circ}$ \\
\hline Outer diameter of the glass $\left(\mathrm{D}_{\mathrm{G}, \mathrm{ext}}\right)$ & $0.02 \mathrm{~m}$ & Rim radius $\left(\mathrm{r}_{\mathrm{r}}\right)$ & $0.75 \mathrm{~m}$ \\
\hline Inside diameter of the glass $\left(\mathrm{D}_{\mathrm{G}, \mathrm{int}}\right)$ & $0.0175 \mathrm{~m}$ & Parabola depth $\left(\mathrm{h}_{\mathrm{p}}\right)$ & $0.15 \mathrm{~m}$ \\
\hline Mirror length $(\ell)$ & $12.27 \mathrm{~m}$ & Opening width of the reflective mirror $(\mathrm{W})$ & $1.2 \mathrm{~m}$ \\
\hline
\end{tabular}

Parabolic trough solar collectors are designed to operate with single-axis tracking. A tracking drive system rotates the manifold about a rotation axis until the Sun central radius and the normal opening area are perpendicular. In addition, the collector performance is still threatened by these factors: reflection loss, absorption loss and losses due to geometric imperfections of the optical system.



Figure 2. Lost areas by the end effect and the blocking effect for the studied collector

Geometric losses are those that occur due to the reduction of the effective area, where they may be inherent to each manifold, or depending on the relative position of the collector between them [73-75]. The geometric factor " $A_{f}$ " is the ratio between the lost area " $A_{l},\left(m^{2}\right)$ " and the opening area " $A_{a},\left(m^{2}\right)$ ", it calculates the effective reduction of the aperture area due to abnormal incidence effects, including blockages, shadows, and loss of radiation reflected from the mirror beyond the end of the receiver tube. When solar radiation is reflected by the reflective mirror to the receiver tube, part of its length does not reach the solar radiation from the reflective mirror because the solar collector is generally horizontal and single axis of followed by the Sun. Thus, during the solar collector from sunrise to sunset, some of the beam radiation reflected near the end of the reflector opposite the sun cannot reach the receiver tube; this is phenomena called the end effect. The lost opening area " $\mathrm{A}_{e},\left(\mathrm{~m}^{2}\right)$ " can be estimated as follows [73, 76]:

$$
A_{e}=F \cdot W \cdot \tan \theta_{i}\left[1+\frac{W^{2}}{48 F^{2}}\right]
$$

Generally, PTCs terminate with opaque plates to avoid unwanted or dangerous concentrations outside the absorber tube. These plates cause the blocking or shading of a portion of the receiver tube, which indeed reduces the 
opening area. For a plate extending from the rim to the rim, Equation (2) can calculate the lost area resulting from shading “ $\mathrm{A}_{\mathrm{b}},\left(\mathrm{m}^{2}\right)[73,76-78]$.

$$
A_{b}=\frac{2}{3} W \cdot h_{P} \cdot \tan \theta_{i}
$$

Therefore, Equation (3) gives the total loss in the opening area.

$$
\begin{gathered}
A_{T L}=A_{e}+A_{b}=F \cdot W \cdot \tan \theta_{i}\left[1+\frac{W^{2}}{48 F^{2}}\right]+\frac{2}{3} \cdot W \cdot h_{P} \cdot \tan \theta_{i} \\
=\left\{F \cdot W\left[1+\frac{W^{2}}{48 F^{2}}\right]+\frac{2}{3} \cdot W \cdot h_{P}\right\} \cdot \tan \theta_{i} \\
=A_{l} \cdot \tan \theta_{i}
\end{gathered}
$$

Therefore, to find the total loss in the opening area "Al, $\left(\mathrm{m}^{2}\right)$ " without taking into account the incidence angle, the two surfaces " $\mathrm{A}_{\mathrm{e}}$ " and " $\mathrm{A}_{\mathrm{b}}$ " are summed without including the term "tan$\left(\theta_{\mathrm{i}}\right)$ " [76, 73]. Finally, the geometric factor " $\mathrm{A}_{\mathrm{f}}$ " is given by $[76,73]$ :

$$
A_{f}=\frac{A_{l}}{A_{a}}=\frac{A_{T L}}{A_{a} \cdot \tan \left(\theta_{i}\right)}
$$

According to Wang et al. [74], the end loss factor " $\eta_{\text {endloss" }}$ " at both ends of the receiver tube in terms of the curve length of the reflective mirror " $\mathrm{CL},(\mathrm{m})$ ", the focal distance "F, (m)" and the incidence angle " $\theta$, $\left({ }^{\circ}\right)$ " can be calculated by Equation (5).

$$
\eta_{\text {endloss }}=1-\frac{F}{\ell} \tan \left(\theta_{i}\right)
$$

In PTC power plants, the reflectors are arranged in rows. The distance " $\mathrm{L}_{\text {spacing, }}(\mathrm{m})$ " between each two consecutive rows is given by:

$$
L_{\text {spacing }}=\max \left[\frac{W \cdot \cos \theta_{i}}{\cos \theta_{Z}}\right]
$$

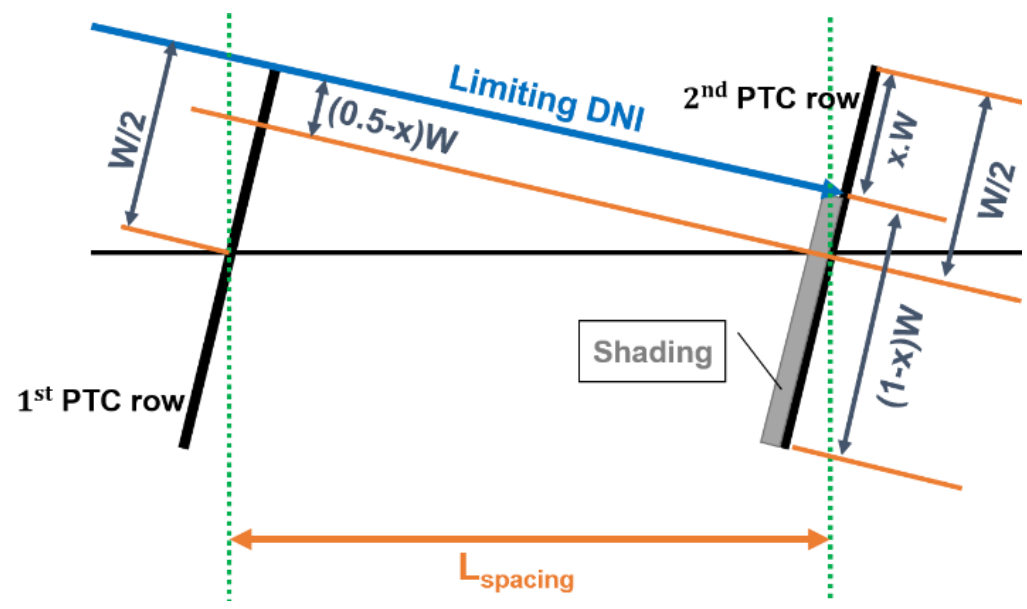

Figure 3. Shaded area in the PTCs field when the distance between the collectors is not sufficient 
With " $\theta_{Z},\left(^{\circ}\right)$ " is the zenith angle in a solar power plant of parabolic trough collectors, the value of the distance "L $\mathrm{L}_{\text {spacing, }}(\mathrm{m})$ " between two consecutive rows of PTCs corresponds to the smallest value of "Cos $\left(\theta_{\mathrm{Z}}\right)$ ".

As it is known, the shadow decreases with the increase of the sun height angle " $\mathrm{h}_{\mathrm{S}},\left(^{\circ}\right)$ ", so it increases proportionally with the increase of the incidence angle " $\theta_{i},\left({ }^{\circ}\right)$ ", therefore, the factor " $\eta_{\text {shadow }}$ " for the calculation of the rank shadow at low solar altitude is given by:

$$
\eta_{\text {shadow }}=1-\frac{A_{\text {shaded }}}{A_{a}}=1-S_{\text {Coef }}
$$

With " $\mathrm{S}_{\mathrm{AR}}=\mathrm{A}_{\text {shaded }} / \mathrm{A}_{\mathrm{a}}$ " is the shaded area rate, while " $\mathrm{A}_{\text {shaded }}\left(\mathrm{m}^{2}\right)$ " is shaded area of the reflective mirror, it can be calculated by Equation (8).

$$
A_{\text {shaded }}=\ell \cdot L_{\text {spacing }} \cdot \cos \left(\tan ^{-1}\left(\frac{\cos \alpha_{S}}{\tanh _{S}}\right)\right)
$$

\section{Optical Errors}

There are two types of optical errors as follow [57, 73]:

- Random errors that are caused by environmental factors where the existing solar collector (error in geometric accuracy of the reflective mirror, mirror reflectivity error, error caused by the presence of dust on the receiver tube and the reflective mirror) [57, 79];

- Non-random errors are directly related to the optical parameters, which depend on the properties of the materials used, the arrangement of the receiver tube in the focal line and the angular errors of the reflective mirror $[57,73]$.

According to Guven et al. [71], the both types of errors (random and non-random) can be combined in one relation in order to determine the universal error parameters for all the concentrator geometries [57, 73]; this relation is the relationship that groups the geometric parameters of the parabolic trough collector.

The intercept factor " $\gamma$ " is the most complicated optical factor in calculating the optical efficiency; it represents the ratio between the energy intercepted by the receiver tube and that reflected by the reflective mirror. For a receiver extending from anointed $\mathrm{A}$ to point $\mathrm{B}$, the intercept factor is given $[37,80]$ :

$$
\gamma=\frac{\int_{A}^{B} D N I(R) d R}{\int_{-\infty}^{+\infty} D N I(R) d R}
$$

Where " $\mathrm{R},(\mathrm{m})$ " is the outer radius of the absorber tube and "DNI, $\left(\mathrm{W} / \mathrm{m}^{2}\right)$ " is the reflected radiation that is incident on the receiver tube surface as shown in Figure (4).

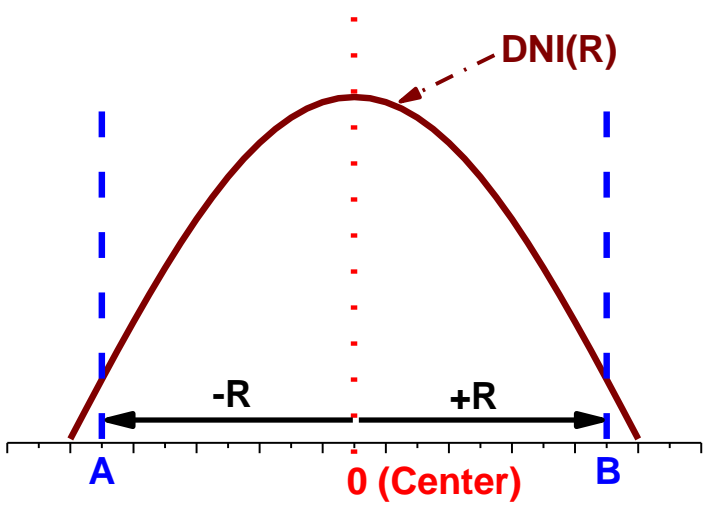

Figure 4. Solar radiation distribution on the receiver tube surface 
The intercept factor " $\gamma$ " takes into account all the errors related to the reflection and concentration of the solar radiation. The main sources of these errors are $[57,73]$ :

- Some of the reflected sunlight from the mirror is not concentrated on the absorbent tube, but reflects outside the focal level of the receiver tube;

- Reflected sun rays do not pass through the receiver tube when reflective mirror shows defects in irregularities;

- The receiver tube is positioned incorrectly in the focal plane;

- Dust or some dirt on reflective mirror or receiver tube.

In addition, these errors may also occur due to some defects caused by improper solar system manufacturing or errors caused by inaccuracies in the tracking system.

Table 2. Optical characteristics of studied PTC

\begin{tabular}{|l|c|}
\hline \multicolumn{1}{|c|}{ Parameter } & Value \\
\hline Overall average optical error $\left(\mathrm{O}_{\text {perror }}\right)$ & $03 \mathrm{mrad}$ \\
\hline Mirror reflection coefficient $\left(\rho_{\mathrm{m}}\right)$ & 0.92 \\
\hline Transmissivity of the glass cover $(\tau)$ & 0.945 \\
\hline Absorption coefficient of the absorber $\left(\alpha_{\mathrm{Ab}}\right)$ & 0.94 \\
\hline The emissivity of the absorber tube $\left(\varepsilon_{\mathrm{Ab}}\right)$ & 0.12 \\
\hline The emissivity of the glass $\left(\varepsilon_{\mathrm{G}}\right)$ & 0.935 \\
\hline
\end{tabular}

The optical efficiency " $\eta_{\mathrm{op}}$ " is the quantity of solar energy absorbed by the receiver tube divided by the amount of direct-normal normal radiation incident on the opening area. The collector optical efficiency can be calculated by Equation (10) [57, 73].

$$
\eta_{o p}=\rho_{m} \cdot \gamma \cdot \tau \cdot \alpha_{A b} \cdot K\left(\theta_{i}\right)
$$

Where the factor " $\mathrm{K}\left(\theta_{\mathrm{i}}\right)$ " is one of the factors to be taken into account in determining the optical efficiency of solar reflectors, it is a coefficient that corrects the incidence angle " $\theta_{\mathrm{i}},\left(^{\circ}\right)$ " of the solar irradiance arrival into the reflective mirror. This coefficient is called the correction coefficient of the incidence angle modifier it can determined from Equation (11) [57, 81].

$$
K\left(\theta_{i}\right)=1-\frac{F}{\ell}\left[\left(1+\frac{W^{2}}{48 F^{2}}\right) \tan \left(\theta_{i}\right)\right]
$$

As conveyed by Kalogirou (2009) [73], the optical efficiency can be calculated using Equation (12).

$$
\eta_{o p t}=\rho_{m} \times \gamma \times \tau \times \alpha_{A b} \times\left(1-A_{f} \tan \left(\theta_{i}\right) \cos \left(\theta_{i}\right)\right)
$$


By comparing the two Equations ( 9 and 11), it is concluded that the correction coefficient of the incidence angle modifier can be calculated based on the relational relationship:

$$
K\left(\theta_{i}\right)=1-\left(A_{f} \cdot \tan \left(\theta_{i}\right) \cdot \cos \left(\theta_{i}\right)\right)
$$

In order to trace the optical behavior of the solar power plant, a program was created on the MATLAB software. This program has allowed the evaluation of all optical factors.

\section{RESULTS AND DISCUSSION Weather Conditions}

All numerical simulation results, as well as the effect of geometric and optical parameters on the evolution of various optical factors and the optical efficiency of a solar power plant of parabolic trough collector will be presented.

This study deals with the optical behavior of the parabolic trough reflectors field in El-Oued region (altitude 62 meters, latitude $33^{\circ} 29^{\prime} 24^{\prime \prime}$ North, longitude 06 $47^{\prime} 50^{\prime \prime}$ East) at Algeria. El-Oued area is characterized by a hot and dry desert climate in summer and a cold climate in winter, with wind in spring. This region is a desert state rich in agricultural resources (water and arable land), and has a large solar radiation. March $16^{\text {th }}, 2018$ was chosen as a day to conduct this optical examination of the studied solar power plant.



Figure 5. Measured values of solar irradiance

As is evident in Figure (5), it is illustrious that the highest value of direct-normal solar irradiance reached $1102.5716 \mathrm{~W} / \mathrm{m}^{2}$ at $10: 50$, and the lowest value reached $5.42891 \mathrm{~W} / \mathrm{m}^{2}$ at 19:00. Moreover, it is obvious that there are some clouds between 11:30 and 15:00.

The variation in the ambient air temperature and the wind speed are shown in Figure (6). The highest value of air temperature touched $29.85^{\circ} \mathrm{C}$ at $08: 50$, and the lowest value was $22.75{ }^{\circ} \mathrm{C}$ at $07: 30$. As for the wind speed, its topmost value recorded in the evening between $16: 00$ and 18:00, where it reached $8.7 \mathrm{~m} / \mathrm{s}$; therefore, this wind speed will not touch the optical performance of the solar power plant because it is near to sunset. As for the lowest value of wind speed is $4.1 \mathrm{~m} / \mathrm{s}$, this value was noted between 10:00 and 12:00. Reality, these meteorological data are encouraging to create the ambition of the establishment of solar power plants fields (Flat, Point and Linear solar collectors [36]) in El-Oued region, Algeria. 


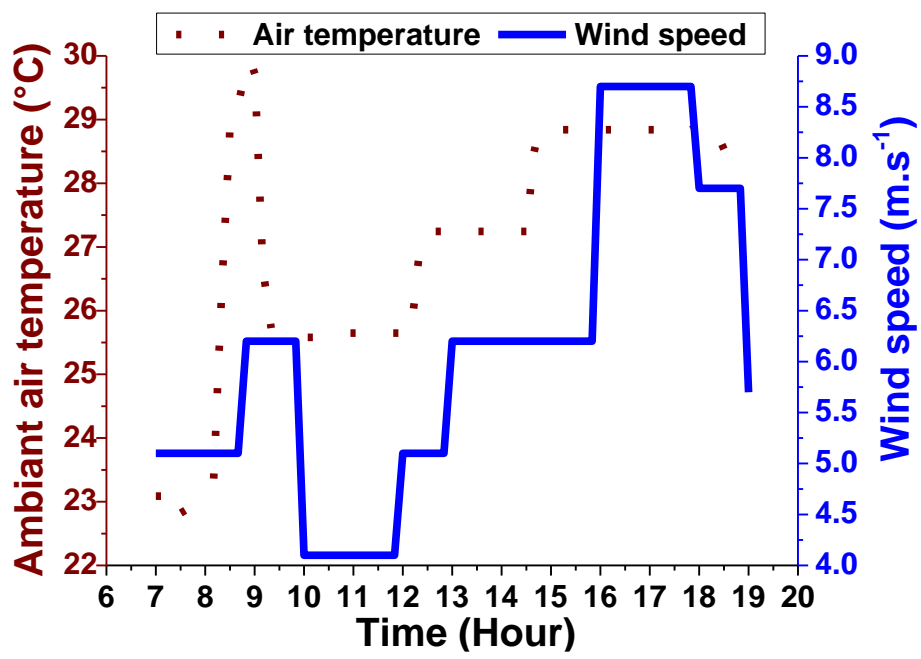

Figure 6. Measured values of the ambient air temperature and the wind speed

\section{Estimation of Incidence and Sun Height Angles}

When referring to the equations mentioned above, it is clear that all optical transactions are directly related to the incidence angle " $\theta \mathrm{i},\left(^{\circ}\right)$ " between the sun's rays and the surface normal. For a horizontal plane, the incidence angle and the zenith angle " $\theta_{\mathrm{Z}},\left(^{\circ}\right)$ " are the same. In the case of solar concentrators, a tracking mechanism is usually used to allow the concentrator to follow the sun. In this study, horizontal east-west tracking for a single-axis tracking mechanism was used, where the receiver tube is parallel to the north-south axis. Therefore, for a PTC collector, the solar energy incident on the opening surface is in function of two parameters:

- The direct-normal solar irradiance;

- The sun position relative to the solar reflector opening.

Therefore, Figure (7) illustrates the evaluation of the incidence angle and the sun height angle versus time for the selected day of study. For reference only, the timing listed in Figure (7) is GTM +2. According to Figure (7), the both angles are contrasted in their evolution from sunrise to sunset. The maximum value of the incidence angle is at sunrise $\left(\theta_{\mathrm{i}}=83.77^{\circ}\right)$ and sunset $\left(\theta_{\mathrm{i}}=89.16^{\circ}\right)$, while the minimum value is at midday $\left(\theta_{\mathrm{i}}=35.6^{\circ}\right)$. As for the sun height angle, its maximum value is at midday $\left(\theta_{\mathrm{i}}=54.40^{\circ}\right)$, and its minimum values are at both ends of the day, i.e., at sunrise $\left(\theta_{\mathrm{i}}=6.23^{\circ}\right)$ and sunset $\left(\theta_{\mathrm{i}}=0.84^{\circ}\right)$. Usually, all solar collectors' types (plan and concentration) are not installed horizontally, but in order to increase the amount of radiation intercepted and to reduce the reflection and the cosine losses.



Figure 7. Assessment of the incidence angle and sun height angle vs. time 


\section{Estimation of Geometric Errors}

Many engineering and design factors reduce PTC's optical performance. These factors are the losses caused by the blockage, the losses caused by the shadows and the losses at the end of the absorber tube (End effect). To solve the problem of thermal losses caused by blocking, the distance between two consecutive rows of PTCs collectors in the same field must be determined with great precision. In addition, the amount of solar energy absorbed by the receiver tube length would be the amplitude of the incoming solar beam radiation multiplied by the correction coefficient of the incidence angle modifier " $\mathrm{K}\left(\theta_{\mathrm{i}}\right)$ ", this coefficient is varied according to the cosine of the incidence angle multiplied by the length of PTC collector. The solar collectors' arrangement series in the field is in the form of parallel rows. Figure (8) proves the evolution of the distance between two rows in a concentrated thermodynamic solar power plant field.

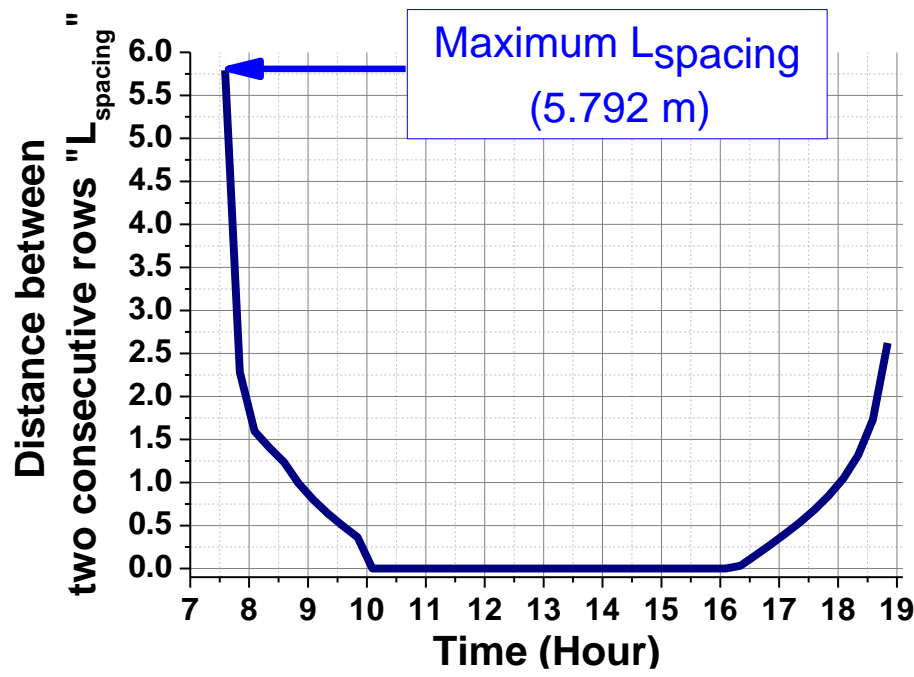

Figure 8. Distance evolution between two consecutive rows

According to Figure (8), the great distance between the field rows is 5.792 meters; this distance will significantly reduce the amount of thermal loss caused by blockage in a solar power plant with the same dimensions as the studied PTC. However, this value corresponds to the time of the sunrise, where the amounts of solar radiation is very weak and does not serve the station. Therefore, the design engineer of the solar station should choose the appropriate distance between two consecutive rows of solar reflectors based on the connection between Figures (5, 6 and 8 ) in order to optimize the investment of the plant and give it a reasonable space.

One of the important parameters that must be precisely defined when working on PTCs is the shading and blocking factors. Figure (9) illustrates the evolution of the lost opening area, the lost area resulting from shading, the factor of the rank shadow at low solar altitude and the shaded area of the reflective mirror.

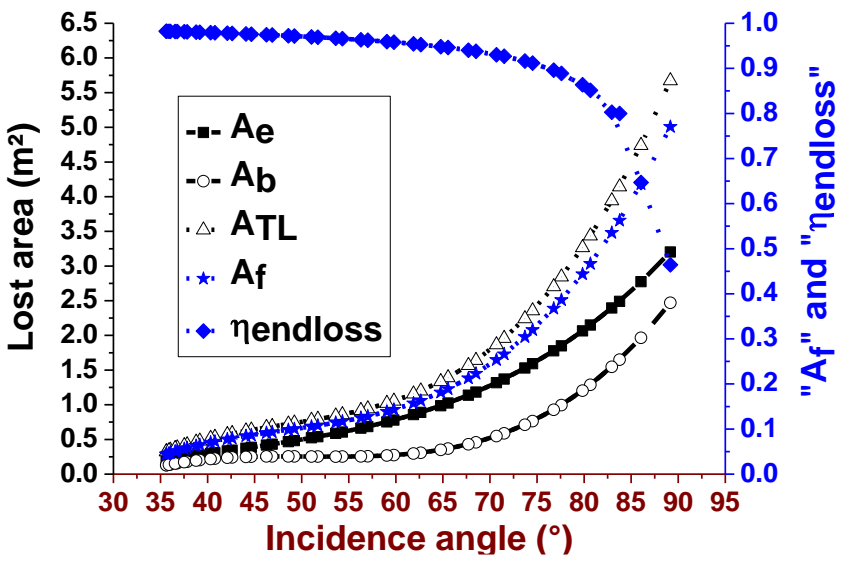

Figure 9. Assessment of geometric losses in terms of incidence angle 
Through Figure (9), it is noted that:

- As for the total loss in the opening area " $\mathrm{A}_{\mathrm{TL}},\left(\mathrm{m}^{2}\right)^{\prime}$, it changes directly with the change of the incidence angle, where it changes proportionally to this angle, this means that increasing the incidence angle value increases the total loss in the opening area. In addition, the maximum value of $A_{\mathrm{LT}}$ is $5.672 \mathrm{~m}^{2}$ at the incidence angle of $89.16^{\circ}$, while the minimum value is 0.323 at $\theta_{\mathrm{i}}=35.61^{\circ}$;

- The geometric factor " $\mathrm{A}_{\mathrm{f}}$ " has a direct relationship with the total loss in the opening area, where it changes proportionally to $A_{\mathrm{LT}}$.As for the maximum value of $\mathrm{A}_{\mathrm{f}}$ is 0.77 at the incidence angle of $89.16^{\circ}$, while the minimum value is 0.043 at $\theta_{\mathrm{i}}=35.61^{\circ}$;

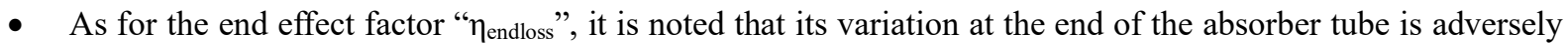
affected by the incidence angle " $\theta_{\mathrm{i}}$ ". Its values are low at sunrise, then start to rise until noon, and then fall back until sunset. As for the minimum value of " $\eta_{\text {endloss }}$ " is 0.46 at the incidence angle of $89.16^{\circ}$, while the minimum value is 0.9825 at $\theta_{\mathrm{i}}=35.61^{\circ}$;

From Figures (7 and 9), it is evident that the all-engineering losses of the studied PTC are significant at sunrise and then decrease until noon, after which they increase again until sunset, as they change directly with the incidence angle. For reference, the incidence angle is changes with the solar zenith angle and the solar azimuth angle. In addition, the geometric dimensions have a direct effect on the change of the geometric error values of the solar reflectors, which is shown in Equations (1-8).

\section{Estimation of Optical Errors}

As shown in Equation (10), the optical efficiency varies with several factors. After conducting this numerical study, it was able to calculate these optical coefficients moment by moment from sunrise to sunset as a function of changing the incidence angle, where the changing these optical coefficients of the studied solar collector is shown in Figure (10). Through Figure (10), it is concluded that:

- The intercept factor " $\gamma$ " varies from 0.92 to 0.971 for incidence angles " $\left.\theta_{\mathrm{i}},{ }^{\circ}\right)$ " changing from 35.61 to 89.16 , where the average value of this factor is 0.967 ;

- By the results obtained from Equation (11), the correction coefficient of the incidence angle modifier " $\mathrm{K}\left(\theta_{\mathrm{i}}\right)$ " varies from 0 to 0.85 for incidence angles changing from 35.61 to 89.16 ;

- By the results obtained from Equation (13), " $\mathrm{K}\left(\theta_{\mathrm{i}}\right)$ " varies from 0 to 0.90 for " $\theta_{\mathrm{i}}$ " changing from 35.61 to 89.16 ;

- The uncertainty between the results obtained from equations 11 and 13 is $0.067 \%$; this uncertainty is acceptable which confirms the accuracy of the results obtained.

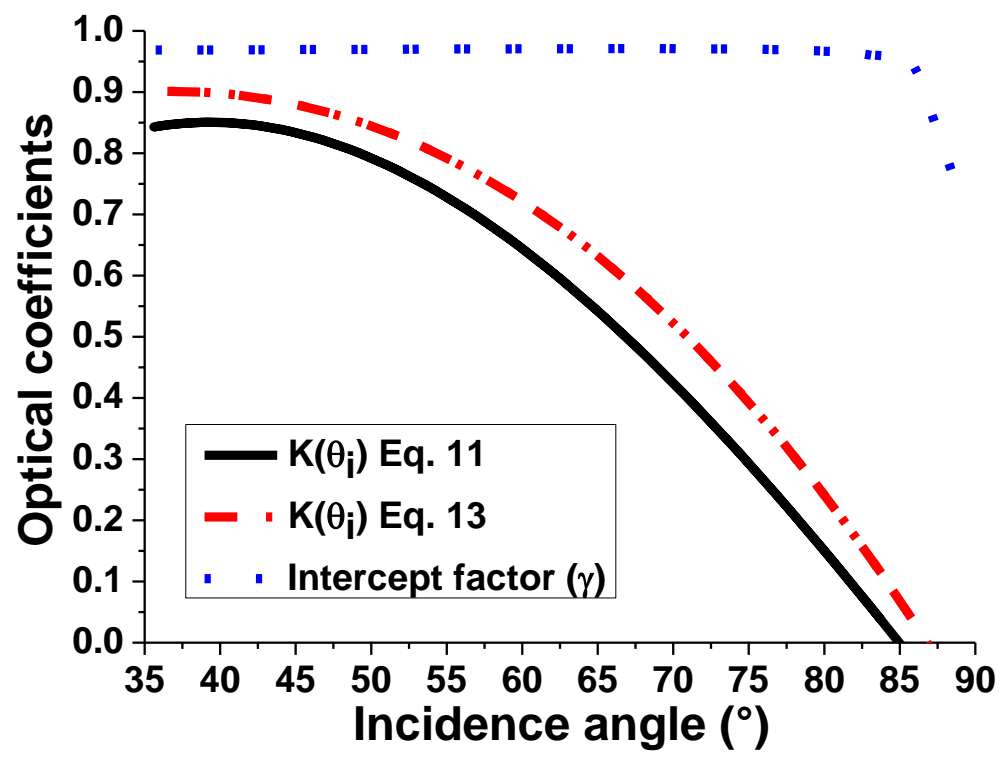

Figure 10. Assessment of the optical coefficients 
Therefore, the curves of Figure (10) show the reasonable values obtained by numerical solution, where the studied solar reflector has optical properties that vary substantially with its geometry. Besides, the change in geometric structure and optical properties of the solar reflector elements directly affects the collector optical efficiency as shown in Figure (11). In addition, the changing beam radiation has a direct effect on the intercept factor in determining optical comportment of the studied device, where Equation (9) shows this which means that the weather data has a direct impact on the efficiency of the device.

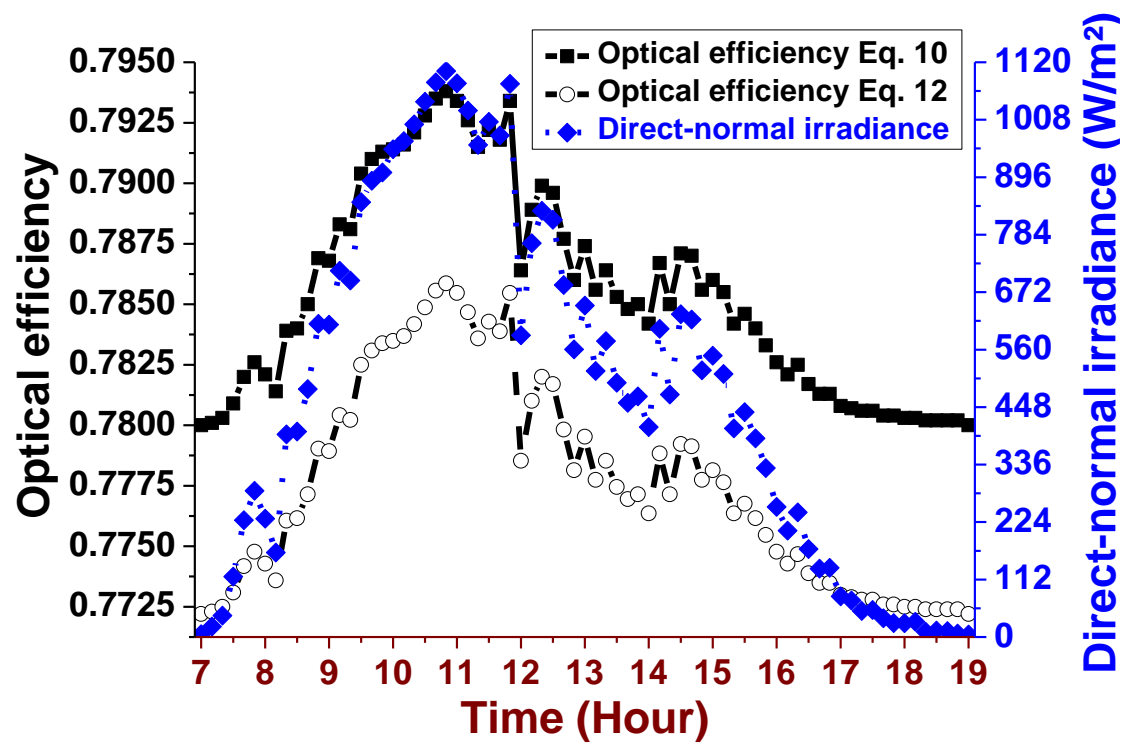

Figure 11. Assessment of the optical efficiencies

Through Figure (11), it is noted that:

- By the results obtained from Equation (10), the minimum value of the optical efficiency " $\eta_{\text {opt }}$ " is $78 \%$ at sunset and sunrise, while its maximum value is equal to $79.38 \%$ at $10: 50$. With regard to its average value is $78.54 \%$;

- By the results obtained from Equation (13), the minimum value of " $\eta_{\text {opt }}$ " is $77.22 \%$ at sunset and sunrise, while its maximum value is equal to $78.59 \%$ at $10: 50$. With regard to its average value is 77.76 ;

- The uncertainty between the results obtained from equations 10 and 12 is $0.78 \%$; this uncertainty is acceptable which confirms the accuracy of the results obtained.

It is noticeable that both equations 10 and 12 have given acceptable values for optical efficiency; in all cases, the efficiency has exceeded $77.22 \%$. In addition, the effect of changing weather data (Beam radiation) is evident on the optical efficiency curves, indicating the accuracy of the results obtained.

When studying a field of this type of solar concentrator, all the previously obtained results should be taken into account, as they directly affect the optical efficiency of solar collectors. Since each sequential concentrator in this field is parallel, the shaded area must be addressed as shown in Figure (12). From Figure (12), it is concluded that:

- The total area of the reflective mirror aperture " $\mathrm{A}_{\mathrm{a}},\left(\mathrm{m}^{2}\right)$ " of the studied collector is $14.724 \mathrm{~m}^{2}$;

- The shaded area is highly valued at sunrise of $14.28 \mathrm{~m}^{2}$, then decreases as the sun height angle " $\mathrm{h}_{\mathrm{s}}$,

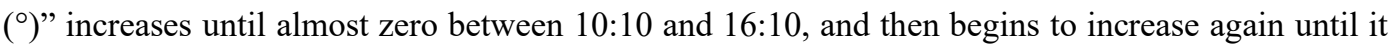
reaches $14.28 \mathrm{~m}^{2}$ at the beginning of sunset;

- The shaded area rate is directly affected by the change of the shaded area; it is increasing by its increase and it is decreasing by its decrease. This means that its maximum value is at sunrise and sunset " $\mathrm{S}_{\mathrm{AR}}=0.97$ ", and its minimum value is between 10:10 and 16:10, a value of about zero; 
- The shading factor " $\eta_{\text {shadow" }}$ " resulting from two consecutive rows of parabolic trough collector varies in reverse completely with the shaded area rate, so its values are very low in the sunrise " $\eta_{\text {shadow }}=0.03$ ", then start increasing until fixed between 10:10 and 16:10 at a value of about one, and then start decreasing again until it reaches the value of 0.03 at the beginning of sunset.

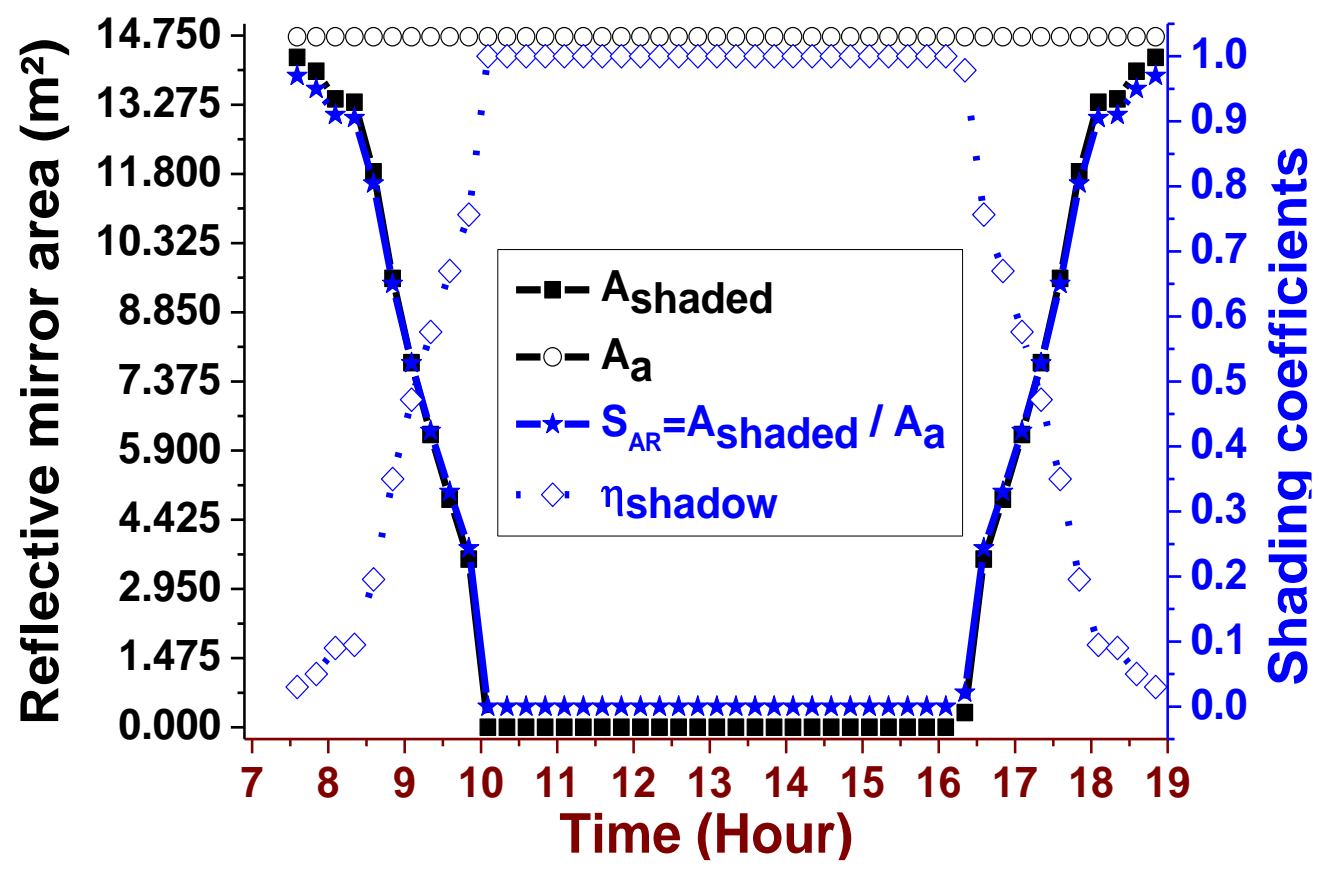

Figure 12. Assessment of the shaded area in in the PTCs solar power plant

As explained above, the solar power plant contains a series of parallel PTCs orbiting around a southern axis that tracks the movement of the sun from sunrise east to sunset west, i.e., each two adjacent PTC lines are arranged in parallel rows. The distance between two rows is conceived by engineers designing the field based on the dimensions of the PTCs solar power plant, climatic conditions and geographic data of the place.

Due to the sun's low solar altitude in the morning, the easternmost array of concentrators (The first row of mirrors located east of the field) will receive full sun, but this row will shade all the next rows to the west. As the sun rises and the collectors follow the sun, this shading effect of the rows decreases until a critical zenith angle is reached and no shading of the rows occurs. The rows of the PTCs remain without shade until the middle of the day, from the end of the morning to the beginning of the afternoon. As seen in Figure (12), losses are introduced by shading the concentrators for about the first and last 120 minutes of operation each day. Generally, the duration of row shading does not vary significantly throughout the year.

Using real weather data for a particular place, the engineering and optical coefficients investigated by this study have a direct effect on the local concentration ratio (LCR) of the beam radiation on the receiver tube, where the local concentration ratio is the ratio between the thermal flow density perceived by the absorber tube and the beam radiation density. So far, there is no empirical work has identified the local concentration ratio and the distribution of concentrated solar radiation flux on the peripheral absorber tube. Figure (13) represents the local concentration ratio distribution on the cross-section of the peripheral absorber tube in terms of beam radiation, with "DNI $=1079 \mathrm{~W} / \mathrm{m}^{2} "$ and $" \theta_{\mathrm{i}}=39.1664^{\circ}$ ". 




Figure 13. Evaluation of the local concentration ratio

Through Figure (13), the maximum value of LCR is equal to 116.30 in the lower part of the absorber tube at the peripheral receiver angles " $\beta=91^{\circ}$ and $269^{\circ}$. The upper part of the circular absorber tube is exposed to the intensity of beam radiation without concentration, where a LCR value of $4.75 \times 10^{-17}$ was recorded at " $\beta=0^{\circ}$. Therefore, it is concluded that the local concentration ratio in the longitudinal direction of the receiver tube is distributed uniformly, but it is irregular in the transverse direction of the receiver tube, where the concentration is very significant values at the bottom of the absorber tube corresponding to the reflective mirror. As for the upper part of the receiver tube, the values the LCR is very weak because it receives the beam radiation directly without concentration.

\section{CONCLUSION}

This paper aims to conduct an optical investigation of a parabolic trough collector in order to show the real optical behavior for the field solar collectors on March $16^{\text {th }}, 2018$ in El-Oued, Algeria. This study allowed determining the geometric and optical errors in terms of real weather data. Numerical simulation based on the analysis and simplification of equations has allowed calculation:

- The change in the cosine effect of the incidence angle " $\theta_{\mathrm{i}},\left(^{\circ}\right)$ ";

- The change in the Sun height angle $" \mathrm{~h}_{\mathrm{s}},\left(^{\circ}\right)$ " from sunrise to sunset;

- The change in the distance " $\mathrm{L}_{\text {spacing, }}(\mathrm{m})$ " between two consecutive rows;

- The change in the total loss in the opening area " $\mathrm{A}_{1},\left(\mathrm{~m}^{2}\right)$ " without taking into account the incidence angle;

- The change in the total loss in the opening area " $\mathrm{A}_{\mathrm{TL}},\left(\mathrm{m}^{2}\right)$ " with taking into account the incidence angle;

- The change in the geometric factor " $\mathrm{A}_{\mathrm{f}}$ ";

- The change in the end effect factor " $\eta_{\text {endloss" }}$ ";

- The change in the intercept factor " $\gamma$ ";

- The change in the correction coefficient of the incidence angle modifier " $K\left(\theta_{i}\right)$ ";

- The change in the shaded area of the reflective mirror " $\mathrm{A}_{\text {shaded, }}\left(\mathrm{m}^{2}\right)$ "; 
- The change in the shaded area rate "S $\mathrm{S}_{\mathrm{AR}}$ ";

- The change in the shading factor " $\eta_{\text {shadow"; }}$

- The change in the optical efficiency " $\eta_{\text {opt }}$ ";

- The change in the local concentration ratio "LCR".

Thus, fourteen important optical parameters were calculated, because before the construction and establishment of any solar power plant with PTC collectors, the engineers must identify these important parameters with big precision.

In all case of this study, the optical efficiency has exceeded 77.22 \%. As for the local concentration ratio, its maximum value is equal to 116.297 in the lower part of the receiver tube at the peripheral receiver angle " $\beta=180^{\circ}$ ", while the minimum values of this important coefficient were recorded at the top of the receiver tube.

Finally, the research team is currently working on the design of an experimental model for this studied solar collector, with the same dimensions and the same characteristics, in order to conduct optical and thermal experiments on it, which opens the prospects for the development of this type of solar concentrators.

\section{NOMENCLATURE}

$A_{a} \quad$ Opening area of the solar collector, $\mathrm{m}^{2}$

$A_{e} \quad$ Lost opening area, $\mathrm{m}^{2}$

$A_{l} \quad$ Total loss in the opening area without taking into account the incidence angle, $\mathrm{m}^{2}$

$A_{b} \quad$ Lost area resulting from shading, $\mathrm{m}^{2}$

$A_{f} \quad$ Ratio between the lost area and the opening area

$A_{G, \text { ext }} \quad$ Extern surface of the glass cover, $\mathrm{m}^{2}$

$A_{r} \quad$ Copper absorber tube surface, $\mathrm{m}^{2}$

$A_{\text {,ext }} \quad$ Outer surface of the copper absorber tube, $\mathrm{m}^{2}$

$A_{\text {shaded }} \quad$ Shaded area of the reflective mirror, $\mathrm{m}^{2}$

$A_{T L} \quad$ Total loss in the opening area in terms of incidence angle, $\mathrm{m}^{2}$

$C L \quad$ Curve length of the reflective mirror, $\mathrm{m}$

$D_{A, \text { ext }} \quad$ Outside diameter of the copper absorber tube, $\mathrm{m}$

$D_{A, \text { int }} \quad$ Inner diameter of the copper absorber tube, $\mathrm{m}$

$D_{G, e x t} \quad$ Outer diameter of the glass cover, $\mathrm{m}$

$D_{G, \text { int }} \quad$ Inside diameter of the glass cover, $\mathrm{m}$

DNI Direct-normal irradiance, $\mathrm{W} / \mathrm{m}^{2}$

$F \quad$ Focal distance, $\mathrm{m}$

$h_{S} \quad$ Sun height angle, ${ }^{\circ}$

$K\left(\theta_{i}\right) \quad$ Correction coefficient of the incidence angle modifier

$L_{\text {spacing }} \quad$ Distance between each two consecutive rows, $\mathrm{m}$

$\ell \quad$ Mirror length, $\mathrm{m}$

$O p_{\text {error }} \quad$ Overall average optical error

$h_{P} \quad$ Parabola depth, $\mathrm{m}$

$R \quad$ Outer radius of the receiver tube, $\mathrm{m}$

$r_{r} \quad$ Rim radius, $\mathrm{m}$

$S_{A R} \quad$ Shaded area rate

$W \quad$ Opening width of the reflective mirror, $\mathrm{m}$ 
Abbreviations

$\begin{array}{ll}\text { CPCS } & \text { Compound parabolic collectors } \\ \text { CPTC } & \text { Compound parabolic trough solar collector } \\ \text { ETCS } & \text { Evacuated tube collectors } \\ \text { FPCS } & \text { Flat-plate collectors } \\ \text { HFCs } & \text { Heliostat field collectors } \\ \text { LFRS } & \text { Linear Fresnel reflectors } \\ \text { PDRs } & \text { Parabolic dish reflectors } \\ \text { PTCS } & \text { Parabolic trough collectors }\end{array}$

Greek symbols

$\begin{array}{cl}\tau & \text { Cover glass transmittance } \\ \gamma & \text { Intercept factor } \\ \varepsilon_{A b} & \text { Absorber tube emissivity } \\ \varepsilon_{G} & \text { Emissivity of glass Cover } \\ \alpha_{A b} & \text { Absorption coefficient of the receiver tube } \\ \alpha_{S} & \text { Solar azimuth angle, }{ }^{\circ} \\ \eta_{\text {opt }} & \text { Optical efficiency } \\ \eta_{\text {endloss }} & \text { End loss factor } \\ \rho_{m} & \text { Primary mirrors reflectivity } \\ \varphi_{r} & \text { Rim angle, }{ }^{\circ} \\ \theta_{i} & \text { Incidence angle, }{ }^{\circ} \\ \theta_{Z} & \text { Zenith angle in a solar power plant of parabolic trough collectors, } \\ \beta & \text { Peripheral absorber angle, }\end{array}$

\section{REFERENCES}

[1] Ghodbane M, Boumeddane B, Said Z, Bellos E. A numerical simulation of a linear Fresnel solar reflector directed to produce steam for the power plant. Journal of Cleaner Production 2019; 231:494-508. https://doi.org/10.1016/j.jclepro.2019.05.201.

[2] Ghodbane M, Benmenine D, Khechekhouche A, Boumeddane B. Brief on Solar Concentrators: Differences and Applications. Instrumentation Mesure Metrologie 2020;19(5):371-378. https://dx.doi.org/10.18280/i2m.190507.

[3] Girard A, Roberts C, Simon F, Ordoñez J. Solar electricity production and taxi electrical vehicle conversion in Chile. Journal of Cleaner Production 2019; 210: 1261-1269. https://doi.org/10.016/j.jclepro.2018.11.092.

[4] Settino J, Sant T, Micallef C, Farrugia M, Staines CS, Licari J, Micallef A. Overview of solar technologies for electricity, heating and cooling production. Renewable and Sustainable Energy Reviews 2018; 90: 892909. https://doi.org/10.1016/j.rser.2018.03.112.

[5] Bouguila A, Said R. Optimization of a Small Scale Concentrated Solar Power Plant Using Rankine Cycle. Journal of Thermal Engineering 2020; 6(3): 268-81. https://dx.doi.org/10.18186/thermal.711287.

[6] Taner T, Dalkilic AS. A Feasibility Study of Solar Energy - Economic Analysis from Aksaray, Turkey. Journal of Thermal Engineering 2019; 5(1): 25-30. https:/dx.doi.org/10.18186/thermal.505498.

[7] Ghodbane M, Bellos E, Said Z, Boumeddane B, Khechekhouche A, Sheikholeslami M, Ali ZM. Energy, Financial and Environmental investigation of a direct steam production power plant driven by linear Fresnel solar reflectors. Journal of Solar Energy Engineering 2021; 143(2): 021008. https://doi.org/10.1115/1.4048158.

[8] Mazzeo D. Solar and wind assisted heat pump to meet the building air conditioning and electric energy demand in the presence of an electric vehicle charging station and battery storage. Journal of Cleaner 
Production 2019; 213: 1228-1250. https://doi.org/10.1016/j.jclepro.2018.12.212.

[9] Ghodbane M, Boumeddane B, Hussein AK. Performance Analysis of a Solar-Driven Ejector Air Conditioning System Under El-Oued Climatic Conditions, Algeria. Journal of Thermal Engineering 2021; 7(1): 172-89. https://dx.doi.org/10.18186/thermal.847334.

[10] Ghodbane M. Étude et optimisation des performances d'une machine de climatisation a éjecteur reliée à un concentrateur solaire. Université Saad Dahlab de Blida 1. 2017.

[11] Ghodbane M, Boumeddane B, Khechekhouche A, Benmenine D. Study of a solar air conditioning system with ejector. International Journal of Energetica (IJECA) 2020; 5(1): 14-21. https://dx.doi.org/10.47238/ijeca.v5i1.115.

[12] Delgado-Marín JP, García FV, García-Cascales JR. Use of a predictive control to improve the energy efficiency in indoor swimming pools using solar thermal energy. Solar Energy 2019; 179: 380-390. https://doi.org/10.1016/j.solener.2019.01.004.

[13] Ghodbane M, Boumeddane B, Moummi N, Largot S, Berkane H. Study and numerical simulation of solar system for air heating. Journal of Fundamental and Applied Sciences 2016; 8(1): 41-60, http://dx.doi.org/10.4314/jfas.v8i1.3.

[14] Singh J, Singh R, Bhushan B. Thermo-Hydraulic Performance of Solar Air Heater Duct having Triangular Protrusions as Roughness Geometry. Journal of Thermal Engineering 2015; 1(7): 607-620. https://dx.doi.org/10.18186/jte.01332.

[15] Yildırım C. Theoretical Investigation of a Solar Air Heater Roughened by Ribs and Grooves. Journal of Thermal Engineering 2018; 4(1): 1702-1712. https:/dx.doi.org/10.18186/journal-of-thermalengineering.365713.

[16] Ghodbane M, Boumeddane B, Said N. A linear Fresnel reflector as a solar system for heating water: theoretical and experimental study. Case Studies in Thermal Engineering 2016; 8(C): 176-186, http://dx.doi.org/10.1016/j.csite.2016.06.006.

[17] Endale A. Analysis of Status, Potential and Economic Significance of Solar Water Heating System in Ethiopia. Renewable Energy 2019; 132: 1167-1176. https://doi.org/10.016/j.renene.2018.08.094.

[18] Kerme E, Kaneesamkandi Z. Performance Analysis and Design of Liquid Based Solar Heating System. Journal of Thermal Engineering 2015; 1(5):182-191. https://dx.doi.org/10.18186/jte.02359.

[19] Bellos E, Said Z, Tzivanidis C. The use of nanofluids in solar concentrating technologies: A comprehensive review. Journal of Cleaner Production 2018; 196: 84-99. https://doi.org/10.1016/j.jclepro.2018.06.048.

[20] Loni R, Asli-Ardeh EA, Ghobadian B, Ahmadi MH, Bellos E. GMDH modeling and experimental investigation of thermal performance enhancement of hemispherical cavity receiver using MWCNT/oil nanofluid. Solar Energy 2018; 171: 790-803. https://doi.org/10.1016/j.solener.2018.07.003.

[21] Rizi AP, Ashrafzadeh A, Ramezani A. A financial comparative study of solar and regular irrigation pumps: Case studies in eastern and southern Iran. Renewable Energy 138: 1096-1103. https://doi.org/10.16/j.renene.2019.02.026.

[22] Powell JW, Welsh JM, Farquharson R. Investment analysis of solar energy in a hybrid diesel irrigation pumping system in New South Wales, Australia. Journal of Cleaner Production 2019;224: 444-454. https://doi.org/10.1016/j.jclepro.2019.03.071.

[23] Costa BA, Lemos JM, Guillot E. Solar furnace temperature control with active cooling. Solar Energy 2018;159: 66-77. http://dx.doi.org/10.1016/j.solener.2017.10.017.

[24] Indora S, Kandpal TC. Financial appraisal of using Scheffler dish for steam based institutional solar cooking in India. Renewable Energy 2019; 135: 1400-1411. https://doi.org/10.016/j.renene.2018.09.067.

[25] Ahmed FE, Hashaikeh R, Hilal N. Solar powered desalination - Technology, energy and future outlook. Desalination 2019; 453:54-76. https://doi.org/10.1016/j.desal.2018.12.002.

[26] Ghasemi A, Hashemian N, Noorpoor A, Heidarnejad P. Exergy Based Optimization of a Biomass and Solar Fuelled CCHP Hybrid Seawater Desalination Plant. Journal of Thermal Engineering 2017; 3(1):1034-1043. https:/dx.doi.org/10.18186/thermal.290251.

[27] Stegou-Sagia A, Fragkou DV. Thin Layer Drying Modeling of Apples and Apricots in A Solar-Assisted Drying System. Journal of Thermal Engineering 2018; 4(1):1680-1691. https:/dx.doi.org/10.18186/journalof-thermal-engineering.364909.

[28] Attia MEH, Driss Z, Ghodbane M, Hussein AK, Rout SK, Li D, editors. Experimental Study of the Temperature Distribution Inside an Indirect Solar Dryer Chamber. Advances in Air Conditioning and Refrigeration; 2021; Singapore: Springer Singapore.

[29] Pulido-Iparraguirre D, Valenzuela L, Aguilera JJ, Fernández-Garcíaa A. Optimized design of a Linear Fresnel reflector for solar process heat applications. Renewable Energy 2019; 131: 1089-1106. 
https://doi.org/10.16/j.renene.2018.08.018.

[30] Farjana SH, Huda N, Parvez-Mahmud MA, Saidur R. Solar process heat in industrial systems - A global review. Renewable and Sustainable Energy Reviews 2018; 82: 2270-2286. http://dx.doi.org/10.1016/j.rser.2017.08.065.

[31] Bellos E, Korres D, Tzivanidis C, Antonopoulos KA. Design, simulation and optimization of a compound parabolic collector. Sustainable Energy Technologies and Assessments 2016; 16: 53-63. https://doi.org/10.1016/j.seta.2016.04.005.

[32] Korres D, Bellos E, Tzivanidis C. Investigation of a nanofluid-based compound parabolic trough solar collector under laminar flow conditions. Applied Thermal Engineering 2019; 149: 366-376. https://doi.org/10.1016/j.applthermaleng.2018.12.077.

[33] Said Z, Saidur R, Rahim NA. Energy and exergy analysis of a flat plate solar collector using different sizes of aluminium oxide based nanofluid. Journal of Cleaner Production 2016; 133: 518-530. https://doi.org/10.1016/j.jclepro.2016.05.178.

[34] Said Z, Saidur R, Sabiha MA, Hepbasli A, Rahim NA. Energy and exergy efficiency of a flat plate solar collector using $\mathrm{pH}$ treated Al2O3 nanofluid. Journal of Cleaner Production 2016; 112: 3915-3926. https://doi.org/10.1016/j.jclepro.2015.07.115.

[35] Said Z, Saidur R, Sabiha MA, Rahim NA, Anisur MR. Thermophysical properties of Single Wall Carbon Nanotubes and its effect on exergy efficiency of a flat plate solar collector. Solar Energy 2015; 115: 757-769. https://doi.org/10.1016/j.solener.2015.02.037.

[36] Kalogirou SA. Solar thermal collectors and applications. Progress in Energy and Combustion Science 2004; 30(3): 231-95. https://doi.org/10.1016/j.pecs.2004.02.001.

[37] Said Z, Ghodbane M, Hachicha AA, Boumeddane B. Optical performance assessment of a small experimental prototype of linear Fresnel reflector. Case Studies in Thermal Engineering 2019: 100541. https://doi.org/10.1016/j.csite.2019.

[38] Ghodbane M, Boumeddane B, Said N. Design and experimental study of a solar system for heating water utilizing a linear Fresnel reflector. Journal of Fundamental and Applied Sciences 2016; 8(3): 804-825, http://dx.doi.org/10.4314/jfas.v8i3.8.

[39] Ghodbane M, Bellos E, Said Z, Boumeddane B, Hussein AK, Kolsi L. Evaluating energy efficiency and economic effect of heat transfer in copper tube for small solar linear Fresnel reflector. Journal of Thermal Analysis and Calorimetry 2020. https://doi.org/10.1007/s10973-020-09384-6.

[40] Kasaeian A, Loni R, Asli-Ardeh EA, Ghobadian B, Shahverdi K. Thermal Evaluation of Cavity Receiver using Water/PG as the Solar Working Fluid. Journal of Thermal Engineering 2019; 5(5): 446-455. https://dx.doi.org/10.18186/thermal.624341.

[41] Kasaeian A, Loni R, Asli-Ardeh EA, Ghobadian B, Shahverdi K. Comparison Study of Air and Thermal Oil Application in a Solar Cavity Receiver. Journal of Thermal Engineering 2019; 5(6): $221-229$. https://dx.doi.org/10.18186/thermal.654628.

[42] Ghodbane M, Boumeddane B, Hussein AK, Ali HM. Thermal numerical investigation of a small parabolic trough collector under desert climatic conditions Journal of Thermal Engineering 2021.

[43] Yettou F. Receiver Temperature Maps of Parabolic Collector Used for Solar Food Cooking Application in Algeria. Journal of Thermal Engineering 2018; 4(1): 1656-1667. https:/dx.doi.org/10.18186/journal-ofthermal-engineering.364866.

[44] Benmenine D, Ghodbane M, Soudani ME, Abdelouahed H, Massiv A, Elsharif N. A small parabolic trough collector as a solar water heater: an experimental study in Ouargla region, Algeria. International Journal of Energetica (IJECA) 2020; 5(2):1-6. https://dx.doi.org/10.47238/ijeca.v5i2.141.

[45] Hussein AK, Ghodbane M, Said Z, Ward RS. The Effect of the Baffle Length on the Natural Convection in an Enclosure Filled with Different Nanofluids. Journal of Thermal Analysis and Calorimetry 2020. https://doi.org/10.1007/s10973-020-10300-1

[46] Said Z, Ghodbane M, Sundar LS, Tiwari AK, Sheikholeslami M, Boumeddane B. Heat transfer, entropy generation, economic and environmental analyses of linear Fresnel reflector using novel rGO-Co3O4 hybrid nanofluids. Renewable Energy 2021; 165(Part 1): 420-37. https://doi.org/10.1016/j.renene.2020.11.054.

[47] Ghodbane M, Said Z, Hachicha AA, Boumeddane B. Performance assessment of linear Fresnel solar reflector using MWCNTs/DW nanofluids. Renewable Energy 2020; 151: 43-56. https://doi.org/10.1016/j.renene.2019.10.137.

[48] Mebarek-Oudina F. Convective heat transfer of Titania nanofluids of different base fluids in cylindrical annulus with discrete heat source. Heat Transfer-Asian Research 2019; 48(1): 135-47. https://doi.org/10.1002/htj.21375. 
[49] Said Z, Abdelkareem MA, Rezk H, Nassef AM. Fuzzy modeling and optimization for experimental thermophysical properties of water and ethylene glycol mixture for $\mathrm{Al} 2 \mathrm{O} 3$ and $\mathrm{TiO} 2$ based nanofluids. Powder Technology 2019; 353: 345-358. https://doi.org/10.1016/j.powtec.2019.05.036.

[50] Said Z, Abdelkareem MA, Rezk H, Nassef AM, Atwany HZ. Stability, thermophysical and electrical properties of synthesized carbon nanofiber and reduced-graphene oxide-based nanofluids and their hybrid along with fuzzy modeling approach. Powder Technology 2020. https://doi.org/10.1016/j.powtec.2020.02.026.

[51] Said Z, Arora S, Bellos E. A review on performance and environmental effects of conventional and nanofluidbased thermal photovoltaics. Renewable and Sustainable Energy Reviews 2018; 94: 302-316. https://doi.org/10.1016/j.rser.2018.06.010.

[52] Said Z, Assad MEH, Hachicha AA, Bellos E, Abdelkareem MA, Alazaizeh DZ, Yousef BAA. Enhancing the performance of automotive radiators using nanofluids. Renewable and Sustainable Energy Reviews 2019; 112: 183-194. https://doi.org/10.1016/j.rser.2019.05.052.

[53] Raza J, Mebarek-Oudina F, Chamkha AJ. Magnetohydrodynamic flow of molybdenum disulfide nanofluid in a channel with shape effects. Multidiscipline Modeling in Materials and Structures 2019; 15(4): 737-57, https://doi.org/10.1108/MMMS-07-2018-0133.

[54] Bellos E, Tzivanidis C. Performance analysis and optimization of an absorption chiller driven by nanofluid based solar flat plate collector. Journal of Cleaner Production 2018; 174: 256-272. https://doi.org/10.1016/j.jclepro.2017.10.313.

[55] Bellos E, Tzivanidis C. Multi-criteria evaluation of a nanofluid-based linear Fresnel solar collector. Solar Energy 2018; 163: 200-214. https://doi.org/10.1016/j.solener.2018.02.007.

[56] Alkasassbeh M, Omar Z, Mebarek-Oudina F, Raza J, Chamkha A. Heat transfer study of convective fin with temperature-dependent internal heat generation by hybrid block method. Heat Transfer-Asian Research 2019; 48(4): 1225-44. https://doi.org/10.002/htj.21428.

[57] Ghodbane M, Boumeddane B. Engineering design and optical investigation of a concentrating collector: Case study of a parabolic trough concentrator J Fundam Appl Sci. 2018; 10(2): 148-71. http://dx.doi.org/10.4314/jfas.v10i2.11.

[58] Ghodbane M, Boumeddane B. A parabolic trough solar collector as a solar system for heating water: a study based on numerical simulation. International Journal of Energetica (IJECA) 2017; 2(2): 29-37. https://dx.doi.org/10.47238/ijeca.v2i2.32.

[59] Bellos E. Progress in the design and the applications of Linear Fresnel Reflectors - A critical review. Thermal Science and Engineering Progress 2019; 10: 112-137. https://doi.org/10.1016/j.tsep.2019.01.014.

[60] Tiwari AK, Kumar V, Said Z, Paliwal HK. A review on the application of hybrid nanofluids for parabolic trough collector: Recent progress and outlook. Journal of Cleaner Production 2021; 292: 126031. https://doi.org/10.1016/j.jclepro.2021.

[61] Ebrazeh S, Sheikholeslami M. Applications of nanomaterial for parabolic trough collector. Powder Technology 2020; 375: 472-492. https://doi.org/10.1016/j.powtec.2020.08.005.

[62] Bellos E, Tzivanidis C. Alternative designs of parabolic trough solar collectors. Progress in Energy and Combustion Science 2019; 71: 81-117. https://doi.org/10.1016/j.pecs.2018.11.001.

[63] Manikandan GK, Iniyan S, Goic R. Enhancing the optical and thermal efficiency of a parabolic trough collector - A review. Applied Energy 2019; 235: 1524-1540. https://doi.org/10.016/j.apenergy.2018.11.048.

[64] Azzouzi D, Bourorga HE, Belainine KA, Boumeddane B. Experimental study of a designed solar parabolic trough with large rim angle. Renewable Energy 2018; 125: 495-500, https://doi.org/10.1016/j.renene.2018.01.041.

[65] Moloodpoor M, Mortazavi A, Ozbalta N. Thermal analysis of parabolic trough collectors via a swarm intelligence optimizer. Solar Energy 2019; 181: 264-275. https://doi.org/10.1016/j.solener.2019.02.008.

[66] Bellos E, Tzivanidis C, Tsimpoukis D. Thermal enhancement of parabolic trough collector with internally finned absorbers. Solar Energy 2017; 157:514-531. https://doi.org/10.1016/j.solener.2017.08.067.

[67] Bellos E, Tzivanidis C. Parametric investigation of nanofluids utilization in parabolic trough collectors. Thermal Science and Engineering Progress 2017; 2: 71-79. https://doi.org/10.1016/j.tsep.2017.05.001.

[68] Bellos E, Daniil I, Tzivanidis C. Multiple cylindrical inserts for parabolic trough solar collector. Applied Thermal Engineering 2018; 143: 80-89. https://doi.org/10.1016/j.applthermaleng.2018.07.086.

[69] Bellos E, Tzivanidis C. Investigation of a star flow insert in a parabolic trough solar collector. Applied Energy 2018; 224: 86-102. https://doi.org/10.1016/j.apenergy.2018.04.099.

[70] Bellos E, Tzivanidis C, Tsimpoukis D. Optimum number of internal fins in parabolic trough collectors. Applied Thermal Engineering 2018; 137: 669-677. https://doi.org/10.1016/j.applthermaleng.2018.04.037. 
[71] Guven HM. Determination of error tolerances for the optical design of parabolic troughs for developing countries. Solar energy 1986;36(6):535-50, http://dx.doi.org/10.1016/0038-092X(86)90018-6.

[72] Ghodbane M, Boumeddane B. Optical modeling and thermal behavior of a parabolic trough solar collector in the Algerian sahara. AMSE JOURNALS-AMSE IIETA, MMC_B 2017;86(2):406-26. https://doi.org/10.18280/mmc_b.860207

[73] Kalogirou SA. Solar Energy Engineering: Processes and Systems. 1st ed. Academic Press; 2009.

[74] Wang J, Wang J, Bi X, W X. Performance simulation comparison for parabolic trough solar collectors in China. International Journal of Photoenergy 2016; Article ID 9260943:1-16. http://dx.doi.org/0.1155/2016/9260943.

[75] Stuetzle TA. Automatic control of the 30 MWe SEGS VI parabolic trough plant University of WisconsinMadison 2002.

[76] Jeter SM, Jarrar DI, Moustafa SA. Geometrical effects on the performance of trough collectors. Solar Energy 1983; 30(2): 109-113, https://doi.org/10.1016/0038-092X(83)90201-3.

[77] Jeter SM. Calculation of the concentrated flux density distribution in parabolic trough collectors by a semifinite formulation. Solar Energy 1986; 37(5): 335-345, https://doi.org/10.1016/0038-092X(86)90130-1.

[78] Jeter SM. Analytical determination of the optical performance of practical parabolic trough collectors from design data. Solar Energy 1987; 39(1): 11-21, https://doi.org/10.1016/S0038-092X(87)80047-6.

[79] Pierucci G, Fontani D, Sansoni P, Lucia MD. Shape Optimization for Parabolic Troughs Working in NonIdeal Conditions. Energy Procedia 2014; 57: 2231- 2240, http://dx.doi.org/10.1016/j.egypro.2014.10.230.

[80] Ochieng RM, Onyango FN. Some Techniques in Configurational Geometry as Applied to Solar Collectors and Concentrators. Solar Collectors and Panels, Theory and Applications. Sciyo; 2010; 357-378.

[81] Duffie JA, Beckman WA. Solar Engineering of Thermal Processes. 4th ed. Wiley; 2013. 